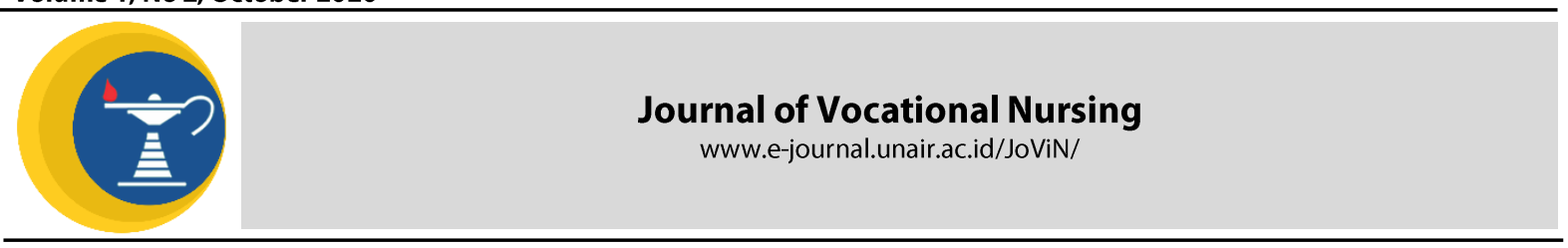

\title{
ANXIETAS AND COPING MECHANISM OF THE FINAL SEMESTER NURSING STUDENTS IN THE SITUATION OF COVID-19
}

Research Report

Endri Ekayamti

Akademi Keperawatan Pemerintah Kabupaten Ngawi

\section{ABSTRACT}

Introduction: The Covid-19 pandemic which hit 215 countries has an impact on all aspects of life for the world community, including Indonesia. One of the most significant impacts is the world of education. The government policy towards education is to do distance learning or learning from home. This changing learning system raises various problems, especially for nursing students. Competencies that must be mastered by nursing students, especially at the final level, apart from a cognitive perspective, are also abilities in the psychomotor field and skills where this ability is obtained by laboratory practice and the ability to provide direct nursing care to patients in the hospital. This change raises its own problems for student psychology, students have feelings of anxiety and worry about their studies. Students also questioned whether they can graduate at the specified time. This study aims to analyze the relationship between anxiety and coping mechanisms in final semester nursing students during the COVID-19 pandemic. Methods: This study used a descriptive correlational design with a cross sectional approach. The population is students of the Akper Pemkab Ngawi in the final semester of the 2018/2019 academic year, the sampling technique used is total sampling with a total of 110 respondents. The anxiety instrument used is the STAI measurement scale and the scale of the coping mechanism. The statistical test used is the Pearson correlation. Results: The results obtained were that there was a significant relationship between anxiety and the coping mechanism used by students with a value of $p=0.007$ for the state anxiety scale and $p=0.000$ for the trait anxiety scale. Conclusion: Based on the results of the study, it can be concluded that the final semester student anxiety during the Covid-19 pandemic is more towards momentary anxiety, where this could have happened because the feeling of uncertainty in their study was related to the covid-19 pandemic.

\section{ARTICLE INFO}

Recived 21 October 2020

Accepted 27 October 2020

Online 29 October 2020

*Correspondence:

Endri Ekayamti

*Email:

yamti.endrieka@gmail.com

\section{Keywords:}

Anxiety, Coping Mechanisms, Final Students, Covid-19

\section{INTRODUCTION}

Currently the world is facing a global pandemic from a disease outbreak caused by the corona virus or what is commonly referred to as covid-19 (corona virus diseases-19). The virus that first appeared in Wuhan China has now spread throughout the world and has affected more than 215 countries including Indonesia. WHO data as of May 29, 2020 shows that to date there are $5,701,337$ positive confirmed cases of Covid-19 from the world's population, and 357,688 (CFR $6.3 \%$ ) people have died from this virus. The United States is the country with the highest cases in the world with a positive confirmation rate of $2,613,092$ cases and 152,212 deaths (WHO, 2020). Data from the Ministry of Health until 29 May 2020 in Indonesia confirmed positive cases of Covid-19 reached 24,538 with a death rate of 1,496 cases. East Java is second only to DKI Jakarta with 4142 confirmed cases of Covid-19, and 334 cases of death (Ministry of Health, 2020). The district health office of Ngawi reported that as of May 29, 2020, there were 12 confirmed positive cases of Covid19 (Dinkes Ngawi, 2020).

The covid-19 pandemic incident led to the implementation of various policies to break the chain of distribution in Indonesia, one of which is to carry out physical distancing for all citizens. The government also implements a Work From Home (WFH) policy where the hope is that all Indonesian people can do work at home. Many sectors have been affected by the Covid-19 
pandemic, one of which is the education sector. The policy in the world of education is that all agencies carry out learning at home. This policy starts from March 16, 2020 until now. UNESCO noted that until April 1, 2020, at least 1.5 billion school-age children were affected by Covid-19 in 188 countries, 60 million of whom were Indonesia. education is expected to stop the teaching and learning process in place and be replaced by the deRector of Telkom Universitas Adiwijaya through a press release Friday 24 April 2020, stating that around 7.5 million students and nearly 45 million Indonesian students are forced to do online learning at home (Medcom Id. 2020). Another visible impact on the world of education in Indonesia includes the cancellation of national examinations at all levels of education units.

With the physical distancing rules, the Ministry of Education issued a policy by dismissing schools and the process of teaching and learning activities which were replaced online. This is based on the Ministry of Education and Culture circular letter number 36962 / MPK.A / HK / 2020 concerning online learning and working from home in the context of preventing Covid-19 for teachers and students at all levels throughout Indonesia (Media Indonesia, 2020). The Ministry of Education and Culture issued a circular number 15 of 2020 concerning guidelines for organizing learning from home in the emergency period of the spread of Covid-19 on May 28, 2020 (Kemendikbud, 2020).

This online learning system often raises several problems, including access to information that is constrained by signals, which causes students to be slow in obtaining information, as well as constraints from the sizeable internet costs. The online learning process in its implementation is mostly only through assignments. Ikhsan (2020), a student majoring in communication at an online newspaper wrote, online learning methods are considered inflexible because when teachers and lecturers provide material, there is a possibility that students and students do not understand the material provided and the lack of a question and answer process due to several problems that make a difference understanding.

The learning system that changed due to the Covid-19 pandemic was also greatly felt by students, especially final semester nursing students. Where in the final semester of nursing students, they have to complete many activities in order to carry out their graduation on time. Obligations that must be passed include abilities in the cognitive, psychomotor and skills fields. In terms of cognitive abilities, students are required to complete scientific papers, and for D3 Nursing students is to provide direct nursing care to patients at the hospital, while the psychomotor abilities and skills of students must pass by carrying out laboratory practices and clinical practice at the hospital. in addition to knowing the soft skills of students, whereas with the covid-19 pandemic conditions and the government's appeal for physical distancing and the existence of a ministerial regulation, it is not possible to place practical students in hospitals or carry out campus learning. Based on several regulations from the government, the Ngawi district government Akper institution finally issued a policy for final year students to meet the competencies they had to complete. Like one of them is the implementation of written guidance and examinations which are carried out online, while for their spikomotor abilities and skills, they have to practice directly at the campus in turn while still following health protocols. The existence of these policies and changes has resulted in many students experiencing anxiety with the uncertainty of their fate.

Syarifah (2013) states that students are prone to experiencing anxiety problems due to demands on a daily basis from their campus, such as assignments, lectures, learning environment, practicum implementation and exams. Exams are the largest source of triggers for anxiety in students. The exam is part of the student's evaluation of the learning process (Basuki, 2015). Anxiety or anxiety is a subjective experience of the individual and this is difficult to observe, but can be identified, namely through changes in individual behavior. Anxiety does not always have a bad impact on a person, sometimes feelings of anxiety are also needed because it can make individuals more alert and eventually motivated to respond, and improve themselves.

Anxieties is a vague feeling of discomfort or worry accompanied by an autonomic response that is often not specific to the individual, a feeling of fear caused by the anticipation of danger (Nanda, 2019). This is a sign of alertness that warns individuals of danger and their ability to act in the face of threats. Anxieties that occur affect the coping mechanisms used by the individual. The coping mechanism used can lead to adaptive and maladaptive coping. Individuals who use the adaptive coping mechanism will be able to reduce the anxiety experienced, whereas if individuals use the maladaptive coping mechanism it can lead to a worse direction such as leading to depression as well as potentially leading to physical health problems (Sholeh, 2012).

The level of anxiety experienced by nursing students in the final semester is not the same, it depends on how the individual's ability to manage anxiety. This condition needs to 
immediately find a solution for treatment from an early age so as not to develop into heavier anxiety. What can be done is with the introduction and awareness of how to manage anxiety appropriately so that later if individuals experience anxiety, they will perceive it as part of the challenge and not the end of everything that cannot be solved (Anelia, 2012).

The adaptive coping mechanism used by students, especially in the final semester students, when experiencing anxiety, will motivate students to learn more to get the best results in the lecture process, so that they pass the lecture as expected. However, if the coping mechanism used is more maladaptive it can result in students becoming discouraged which can lead to a level of depression. Saudale (2016), in his writing stated that the case of a student from a well-known university in Indonesia experienced depression because his score decreased and his thesis was rejected by his supervisor. The same thing from the detik news article wrote in the alleged stress of a student's thesis committing suicide in his boarding house (Wawan, 2020). The results of research conducted by Krisdianto (2015) found that there was a significant relationship between coping mechanisms and the level of depression in final semester students.

The coping mechanism is an individual effort to overcome psychological problems such as anxiety (Potter and Perry 2010). If the coping mechanism used is successful, then the individual will be able to adapt to anxiety, and will not cause health problems, but if the coping mechanism used fails it means that the individual fails to adapt so that health problems will arise both physical, psychological and behavioral (Keliat, 2001).

Based on the above background, the authors are interested in conducting research on the level of activity and coping mechanisms used by final semester nursing students in completing their studies amid the Covid-19 pandemic due to several changes and policies from both the government and the campus.

\section{MATERIALS AND METHODS}

This type of research is quantitative research, using a descriptive correlational research design.
The design of this study was a crosssectional study in which researchers looked for a relationship between anxiety and coping mechanisms for the final semester of the final semester of the Ngawi District Government Akper students in the midst of the Covid-19 pandemic outbreak. The population is students of Akper Pemkab Ngawi in the final semester of the 2018/2019 academic year with the sampling technique used is total sampling and a sample of 110 respondents was obtained. The research was conducted from May to June 2020 at the Akper Pemkab Ngawi.

The instrument for measuring the level of anxiety in this study used the STAI (State Trait Anxiety Inventory) measurement scale from Spielberg (1983) containing 30 statements consisting of favorable and unfavorable statements. STAI validity test with the results of the item correlation coefficient ranged from 0.65 to 0.88 , which means that the statement items in this questionnaire were declared valid. The reliability test by McDowell (2006) with alpha reliability coefficient for state anxiety of 0.93 and trait anxiety of 0.91 .

The coping mechanism instrument was adopted from research conducted by Anelia (2012). Consists of 19 statements covering coping that individuals use when solving problems. The results of the validity test on the coping mechanism questionnaire obtained a value range of 0.16 to 0.663 which means that all statements are declared valid and the reliability value is 0.706 where the value on the two scales is $>0.60$ which means reliable. Data collection was done by writing a questionnaire on a google form, which then shared the goole form link with students. Students fill out the research questionnaire form given which includes a statement of willingness to be research respondents, the identity of the respondent, the anxiety questionnaire (STAI) and the coping mechanism questionnaire. The data collected was then analyzed with statistics. The univariate analysis on the characteristics of the respondents used descriptive analysis, while the bivariate analysis was used to determine the relationship between the level of anxiety and the coping mechanism of students using the person test because after the normality test the data were normally distributed. 


\section{RESULTS}

Table 1 Distribution of Characteristics of Respondents Based on Gender and Age of Nursing Students in the Final Semester of the Ngawi District Government Akper $(n=110)$

\begin{tabular}{ccc}
\hline \multirow{2}{*}{ Respondent Characteristics } & \multicolumn{3}{c}{ Amount } \\
\cline { 2 - 3 } & $\mathbf{n}$ & $\%$ \\
\hline Gender & 26 & 23.6 \\
Male & 84 & 76.4 \\
Women & 110 & 100 \\
Total & & \\
Age & 23 & 20.9 \\
20 years & 55 & 50.0 \\
21 years & 21 & 19.1 \\
22 years & 7 & 6.4 \\
23 years & 3 & 2.7 \\
24 years old & 1 & 9 \\
25 years & 110 & 100 \\
Total & & \\
\hline
\end{tabular}

Based on table 1, it can be seen that the characteristics of respondents based on gender, most of the respondents were women as many as 84 respondents (76.4\%) with 21 years of age as many as 55 respondents (50\%).

Table 2 Frequency Distribution of Nursing Student Anxieties Levels in the Final Semester Akper Ngawi Regency Government in the Covid-19 Pandemic situation ( $n=110)$

\begin{tabular}{ccc}
\hline Anxietas Level & Frequency (n) & Percentage (\%) \\
\hline State Anxiety & 19 & \\
Mild Anxietas & 60 & $17.3 \%$ \\
Moderate anxiety & 31 & $54.5 \%$ \\
Heavy Anxieties & 110 & $28.2 \%$ \\
Total & & $100 \%$ \\
\hline Trait Anxiety & 27 & \\
Mild Anxietas & 77 & $24.5 \%$ \\
Moderate anxiety & 6 & $70.0 \%$ \\
Heavy Anxieties & 110 & $5.5 \%$ \\
Total & $100 \%$ \\
\hline
\end{tabular}

Based on table 2 , it can be seen that on the state anxiety scale most of the respondents were at the moderate anxiety level, some 60 (54.5\%) of respondents, while a small proportion were at the mild anxiety level of 19 (17.3\%) respondents. On the trait anxiety scale, it can be seen that most of the student anxiety levels were at moderate anxiety, as many as $77(70 \%)$ respondents, while a small proportion of respondents were at the severe anxiety level, as many as $6(5.5 \%)$ respondents.

Table 3 Frequency Distribution of Coping Mechanisms in Nursing Students in the Final Semester of the Ngawi District Government Akper in the Covid-19 Pandemic Situation $(n=110)$

\begin{tabular}{ccc}
\hline Anxietas level & Frequency (n) & Percentage (\%) \\
\hline Maladaptive & 25 & $22.7 \%$ \\
Adaptive & 85 & $77.3 \%$ \\
Total & 110 & $100 \%$ \\
\hline
\end{tabular}

In the distribution of the coping mechanism based on table 3, it can be seen that most of the respondents used the adaptive coping mechanism, namely 85 (77.3\%) respondents, while a number of $25(22.7 \%)$ respondents used the maladaptive coping mechanism. 
Table 4 The Cross Distribution of State Anxiety with the Coping Mechanism of Nursing Students in the Final Semester of the Ngawi District Government Akper in the Covid-19 Pandemic Situation $(n=110)$

\begin{tabular}{|c|c|c|c|c|c|c|}
\hline \multirow{3}{*}{ Anxietas level } & \multicolumn{4}{|c|}{ Coping Mechanism } & \multirow{2}{*}{\multicolumn{2}{|c|}{ Total }} \\
\hline & \multicolumn{2}{|c|}{ Adaptive } & \multicolumn{2}{|c|}{ Maladaptive } & & \\
\hline & $\mathbf{n}$ & $\%$ & $\mathbf{n}$ & $\%$ & $\mathbf{n}$ & $\%$ \\
\hline Light & 18 & 16.4 & 1 & 0.9 & 19 & 17.3 \\
\hline Moderate & 44 & 40 & 16 & 14.5 & 60 & 54.5 \\
\hline Weight & 23 & 20.9 & 25 & 22.7 & 31 & 28.2 \\
\hline Total & 85 & 77.3 & 42 & 38.1 & 110 & 100 \\
\hline
\end{tabular}

Based on table 4, the data on the results of the cross distribution between the anxiety level on the state anxiety scale and the coping mechanism shows that most respondents with moderate anxiety levels use the adaptive coping mechanism as many as 44 (20.9\%) of the respondents, while respondents with mild anxiety levels use the adaptive coping mechanism. a total of $18(16.4 \%)$ respondents. Respondents with severe anxiety using maladaptive coping mechanisms were 25 (22.7\%) and respondents with mild anxiety using maladaptive coping mechanisms were $1(0.9 \%)$ respondents.

Table 5 Cross Distribution of Trait Anxiety with the Coping Mechanism of Nursing Students in the Final Semester of the Ngawi District Government Akper in the Covid-19 Pandemic Situation ( $n=110)$

\begin{tabular}{|c|c|c|c|c|c|c|}
\hline \multirow{3}{*}{ Anxietas level } & \multicolumn{4}{|c|}{ Coping Mechanism } & \multirow{2}{*}{\multicolumn{2}{|c|}{ Total }} \\
\hline & \multicolumn{2}{|c|}{ Adaptive } & \multicolumn{2}{|c|}{ Maladaptive } & & \\
\hline & $\mathbf{n}$ & $\%$ & $\mathbf{n}$ & $\%$ & $\mathbf{n}$ & $\%$ \\
\hline Light & 27 & 24.5 & 0 & 0 & 27 & 24.5 \\
\hline Moderate & 56 & 50.9 & 21 & 19.1 & 77 & 70 \\
\hline Weight & 2 & 1.8 & 4 & 3,6 & 6 & 5.5 \\
\hline Total & 85 & 77.3 & 25 & 22.7 & 110 & 100 \\
\hline
\end{tabular}

Based on table 5, the results of cross tabulation of anxiety levels on the state anxiety scale, most of the respondents with moderate anxiety levels used an adaptive coping mechanism of 56 (50.9\%), and a severe level of anxiety using an adaptive coping mechanism of 2 (1.8\%). 21 respondents with moderate anxiety level used maladaptive coping mechanisms (19.1\%).

Table 6 Analysis of the relationship between anxiety and the coping mechanism of the Nursing Students' Final Semester Akper Ngawi District Government in the Covid-19 Pandemic Situation $(n=110)$

\begin{tabular}{ccc} 
Variable & Rs & P value \\
Anxietas Menkanism Coping & & 0.007 \\
State anxiety & -0.254 & 0,000 \\
Trait anxiety & -0.518 & \\
\hline
\end{tabular}

Based on table 6 , the results of the statistical analysis of the relationship between anxiety on the state anxiety scale with the coping mechanism using the Pearson correlation obtained a value of $P=0.007$ where $p<0.05$, which means that there is a significant relationship between anxiety and coping mechanisms in late semester nursing students during the Covid-19 pandemic. . On the trait anxiety scale, the value of $P=0.000$ where $p$ $<0.05$, which means that there is a significant relationship between anxiety and the coping mechanism of nursing students in the last semester during the Covid-19 pandemic.

\section{DISCUSSION}

Age

The Indonesian Ministry of Health (2009) writes that adolescents are grouped into two categories, namely early adolescents with an age range of 12-16 years and late adolescents with an age range of 17-25 years (Amin, 2017). The results showed that most respondents were at the age of 20 years $(50 \%)$ where the range was late adolescence. In line with research conducted by Cupak et al, (2016) which states that most nursing students who experience anxiety are late adolescents, namely the age range of 20 years. The same study conducted by Muyasaroh et al (2020) wrote that most respondents who experienced anxiety were in the age range of 20-24 years. At that age a person is able to socialize psychologically and independently. but at teens 
this age will also experience some psychological changes such as emotional instability and too sensitive, such as crying easily and worrying about something that is not clear why. This can make adolescents behave aggressively towards some of the problems they face, and it is usually more common in women.

\section{Gender}

Based on the research results, it was found that most of the respondents were women as many as 84 (76.4\%). Bahadir (2016) wrote that stress often occurs in female students than male students. The results of this study are also in line with research conducted by Raudah et al (2015) which states that the highest percentage of anxiety levels are women.

The results showed that the level of anxiety in female students was higher than that of male students. These results are also in line with research conducted by (Lun et al, 2018; Quek et al, 2019; Savitsky et al, 2020). This could have happened in this study because the majority of the nursing student population were women. Wulandari in Lau (2019) explains the society's opinion that the nursing profession is more suitable for those with the female gender, assuming they are more diligent, painstaking and patient. Women are also considered to have an open nature compared to men. Besides that, it is also the opinion that the nursing profession is identical to women because it has caring characteristics than men.

\section{Anxietas}

Nursing education is one of the most emotionally stressful studies, it is associated with high academic demands and expectations when carrying out nursing care activities. The main sources of nursing student anxiety mainly come from heavy workloads, task demands, and patient care (Lambrague, 2018).

Anxieties are common among students, the three main concerns that occur in students are academic performance, pressure to succeed, and post-graduation plans (Beiter et al 2015 in Savitsky 2020)

Based on the results of the study, it was found that the anxiety level of the final semester students of the Ngawi District Government Akper during the pandemic period was mostly in the moderate anxiety level. according to the level of state anxiety of respondents who are in moderate anxiety as many as 60 (54.5) respondents, as well as for the trait anxiety level of respondents who are at moderate anxiety level as many as 77 (70\%) of respondents.
State anxiety is an anxiety that arises in a person when faced with something that is considered threatening and temporary or temporary anxiety, while for trait anxiety is an anxiety that persists in a person which is a differentiator between one individual and another (Speilberg, 1983). According to Speilberg (1983) there is a relationship between basic anxiety (trait anxiety) and stait anxiety, where the heavier the trait anxiety will make the state anxiety experienced by students become heavier. In this study, students with temporary anxiety (stait anxiety) with a greater weight category were 31 respondents while on basic anxiety there were 6 respondents. From this it can be concluded that the anxiety of the final semester students during the Covid-19 pandemic is more in the direction of momentary anxiety, where this could have happened because the feeling of uncertainty in their study was related to the covid-19 pandemic. Where there are still many competencies that students should go through until finally they can graduate and graduate according to the predetermined time.

In line with research conducted by Savitsky et al (2020), it was found that the average nursing student during the Covid-19 pandemic experienced high levels of anxiety. The high prevalence of anxiety among students is because during the Covid-19 pandemic they are faced with extraordinary life situations and conditions. These circumstances include them being required to live at home, economic instability, uncertainty of the future, challenges of distance learning, fear of being infected and others.

Anxieties experienced by nursing students occur because of the emotional demands placed on them, where they later have the responsibility to care for patients directly. The impact of this fitness will cause difficulties for students, because they are currently in the process of acquiring personality competencies. Based on this, it is very important for students to be able to manage their level of anxiety, so the hope is that the anxiety they face is used as a positive factor. Increased self-esteem and self-confidence, great self-satisfaction, and increased concentration and the use of appropriate coping mechanisms can increase better performance in learning for nursing students (Cupak et al, 2016).

Research by Ahmed and Badria (2019) found that the main causes of anxiety in students are due to noise, movement to practice, social interaction and personal problems, while the trigger factors for anxiety include caring for patients, tasks and workloads, lack of knowledge and professional skills. , fields of practice and daily life. 


\section{Coping mechanism}

The results showed that most of the coping mechanisms used by respondents were in the range of adaptive coping mechanisms, namely $85(77.3 \%)$ of respondents. Ahmed and Badria (2019) in their research wrote the coping strategies that nursing students use when experiencing anxiety is to take a problem-solving approach, and remain optimistic. In line with the article written by Labrague at,al (2018) which states that the coping mechanism strategies used by students most often are problem solving, formulating plans and problem priorities in dealing with anxiety.

Improving communication such as joking with friends is known to be used as an effective coping strategy to reduce anxiety levels in students (Savitsky et al, 2020). The strategies suggested to help nursing students adapt and effectively deal with their anxiety are peer and teaching staff approaches, providing social support and professional networks, creating a conducive learning environment, and proactive learning (Labrague et al, 2018).

The use of a structured mentorship program was found to be effective in reducing psychological anxiety and increasing the confidence of nursing students (Raymond and Sheppard 2017).

Savitsky et al (2020) mentioned that the most important way to help students during this pandemic is to continue to communicate with them outside of online learning. Students face severe anxiety related to economic uncertainty, fear of their family's health, fear of infection, and face challenges in distance learning. It is also hoped that they will continue to encourage and motivate them through this challenging pandemic.

The use of adaptive coping mechanisms is very important to manage student anxiety. Based on the theory, it suggests two coping styles that can be used, namely: focus on emotions and focus on problems (Folkman and Lazarus in Lambrague et al (2018), where this coping will be useful because it directly reduces the main causes of anxiety and offers long-term solutions to anxiety which are very important for improve individual health and well-being.

This is different from the research written by Savitsky et al, (2020 which revealed that the coping strategies used by students when experiencing anxiety during the Covid-19 pandemic were directed towards calming themselves down, such as alcohol use, sedatives, and overeating. This is a coping strategy. ineffective which can exacerbate student anxiety levels In line with the research of Zheng et al,
(2020) which wrote that maladaptive coping strategies are more likely to lead to eating disorders.

\section{Anxietas and coping}

The results of this study found that there was a significant relationship between anxiety and student coping mechanisms. Anxiety is common for every student, Beiter et al (2015) in Savitsky et al, 2020 stated that there are three main things that concern students in carrying out education, namely academic performance, pressure to succeed, and post-graduation plans. Heavy tuition loads, always experiencing pressure to achieve high average scores (Chen et al, 2015), caring for chronic patients when practicing clinics in hospitals (Sancar et al 2018), this is what causes nursing students to have a high level of anxiety. greater than students from other disciplines (Savitsky et al, 2020).

In this study, the level of student anxiety for the state anxiety scale found that most of the students experienced moderate levels of anxiety and used an adaptive coping mechanism of 44 respondents. Likewise, on the trait anxiety scale, most of the respondents were at a moderate level of anxiety and used an adaptive coping mechanism of 56 respondents. Some theories suggest that anxiety is not always a negative effect on a person. The anxiety that occurs in students can be used to motivate them positively in increasing achievement during education (Alshahrani, 2018). Being aware of feelings of anxiety enables them to develop coping mechanisms to manage stress during education.

The results showed that students with severe anxiety levels mostly used the maladaptive coping mechanism with a total of 25 respondents. Cupak's et al research (2016) found that students who experience high levels of anxiety in difficult situations more often choose coping strategies such as surrender, giving up and blaming themselves. A person with low self-adjustment often uses strategies toward denial and inaction and blames himself for times of anxiety.

Anxieties and coping are both complex processes that develop and change through all phases of life as a result of biological changes, individual personal skills and behavior, individual adaptation processes, and socio-contextual influences (Lambrague, 2018). Research conducted by Alshahrani et al (2018) stated that anxiety that occurs in nursing students can occur due to the fear that they will make mistakes that can harm or kill the patient, worried that all their actions will be judged by clinical lecturers, afraid of breaking academic rules and instructions. 
Based on several studies written by Lambrague (2018), it was found that students at high or late levels experienced higher anxiety than students in the initial semester. Watson et al (2017) students with the final semester experience greater anxiety due to an increase in workload and greater responsibility and an increase in their professional stressors.

Anxieties arise from a busy environment so that students need to work hard and try to learn. Students focus on completing daily tasks and carry out routine care for patients, and they become frustrated because they are not able to learn more complex clinical reasoning and treatment methods for patients, especially since this is a clinical practicum for final semester students. Research conducted by (Admi et al, 2018) states that the conflict between professional beliefs and practical reality in hospitals is a cause of stress for final semester students.

Anxiety has a negative effect on the quality of life of students, education and clinical practice (Sanad, 2019). Karaca et al, 2019 wrote of stress and anxiety during education in nursing as an important risk factor for psychological problems. Long-term uncontrolled anxiety has a negative impact on mental / physical health and academic success of nursing students. The negative effect of anxiety is directly related to the adequacy of individual coping behaviors. The coping strategies used also affect the physical and mental health of individuals. Students with a maladaptive coping mechanism have a higher risk of experiencing mental health than those who have an adaptive coping mechanism. Students with coping strategies are optimistic, problem solving, and coping strategies by sharing feelings are a factor in avoiding one's mental health problems. Therefore, the support from people around them to improve the anxiety-coping skills given by lecturers to students is quite important in order to protect students' mental health (Karaca et al, 2019).

\section{CONCLUSION}

Most of the final semester student anxiety levels on the state anxiety scale were in a moderate level of anxiety, as well as for the trait anxiety scale, but on the instantaneous anxiety on the state anxiety measurement the percentage was greater. Students with stait anxiety with a weight category are greater than the results of the trait anxiety measurement scale. The feeling of uncertainty in their study is related to some changes and policies in the study process during the COVID-19 pandemic. Even so, most of the nursing students in the final semester of the Ngawi District Government Academy of Sciences use adaptive coping mechanisms in dealing with the anxiety they feel during the Covid-19 pandemic.

\section{REFERENCES}

Ahmed. Waled A.M., and Badria M.A. Mohammed. (2019). Nursing students' stress and coping strategies during clinical training in KSA. Journal of Taibah University Medical Sciences 14 (2), 116-122

Alsharani, Yousef, Lynette Cusack, A/Prof, Philippa Rasmussen. (2018). Undergraduate Nursing Students' Strategies For Coping With Their First Clinical Placement. Nurse Education Today (69)104-108. https://doi.org/10.1016/j.nedt.2018.07.00 5

Amin, Muchammad Al dan Dwi Juniati. (2017). Klasifikasi Kelompok Umur Manusia Berdasarkan Analisis Dimensi Fractal Box Counting Dari Citra Wajah Dengan Deteksi Tepi Canny. Jurnal IImiah Matematika. volume 2 no. 6 hal 33-42

Anelia, Niky. (2012). Hubungan Tingkat Stress Dengan Mekanisme Koping Pada Mahasiswa Regular Program Profesi Ners FIK UI Tahun Akademik 2011/2012. Repository FIK UI

Basuki, I., \& Hariyanto. (2015). Asesment Pembelajaran. Remaja Rosdakarya Offset: Bandung.

Chen, C. J. et al. (2015) 'The prevalence and related factors of depressive symptoms among junior college nursing students: A crosssectional study', Journal of Psychiatric and Mental Health Nursing, 22(8), pp. 590-598. doi: 10.1111/jpm.12252.

Cupak, Iwona Bodys, Anna Majda, Joanna Zalewska Puchala, Alicja Kaminska. (2016). The impact of a sense of selfefficacy on the level of stress and the ways of coping with difficult situations in Polish nursing students. Nurse Education Today. Volume $\quad 45 \quad 102-107$ https://doi.org/10.1016/j.nedt.2016.07.00 4

Dinas Kesehatan Kabupaten Ngawi. (2020). https://web.facebook.com/Dinas-

Kesehatan-Kabupaten-Ngawi309496912405876 diakses tanggal 29 Mei 2020 jam 18.00

Folkman. Susan, Richard S.Lazarus. 1988. The relationship between coping and emotion: Implications for theory and research. Social Science \& Medicine. Volume 26, Issue 3, Pages 309-317. https://doi.org/10.1016/02779536(88)90395-4 
Ikhsan, Muhammad. (2020). Belajar secara daring pada era pandemi Covid-19, efektifkah?. Surat kabar online GoRiau.com Surat kabar online https://www.goriau.com/berita/baca/bel ajar-secara-daring-pada-era-pandemicovid19-efektifkah.html diakses tanggal 30 mei 2020 jam 21.15

Kemenkes. (2020). Media informasi terkini penyakit infeksi emerging. https://covid19.kemkes.go.id/situasiinfeksi-emerging/info-coronavirus/situasi-terkini-perkembangancoronavirus-disease-covid-19-29-mei2020/\#.XueLb8ozbIV di akses tanggal 29 mei 2020 jam 21.20

Kemendikbud.

(2020). https://www.kemdikbud.go.id/main/blo $\mathrm{g} / 2020 / 05 /$ kemendikbud-terbitkanpedoman-penyelenggaraan-belajar-darirumah. Diakses tanggal 30 Mei 2020 jam 10.00

Keliat, Budi Anna dkk. (2001). Penatalaksanaan Stres. Jakarta: Penerbit Buku Kedokteran EGC

Krisdianto, Muhammad Agung. Mulyanti. (2015). Mekanisme Koping Berhubungan Dengan Tingkat Depresi Pada Mahasiswa Tingkat Akhir. Journal Ners And Midwifery Indonesia. Vol 3, No 2 hal 71-76

Karacaa. A, N. Yildirima, S. Cangurb, F. Acikgoza, D. Akkusa. (2019). Relationship between mental health of nursing students and coping, selfesteem and social support. Nurse Education Today 76 Hal 44-50. https://doi.org/10.1016/j.nedt.2019.01.02 $9 \mathrm{R}$

Labraguea. Leodoro J, Denise M. McEnroePetitteb, Janet Alexis A. De Los Santosc, Olaide B. Edet. (2018). Examining stress perceptions and coping strategies among Saudi nursing students: A systematic review. Nurse Education Today 65 hal 192-200.

https://doi.org/10.1016/j.nedt.2018.03.01 2

Lau, Deasy Kristiana, Venti Agustina, Heri Setiawa. (2019). Gambaran Tingkat Ansietas Dan Mekanisme Koping Pada Mahasiswa Keperawatan Dalam Menghadapi Ujian Praktik Laboratorium. Jurnal keperawatan jiwa volume 7 No 2, hal 215-226

Levett-Jones, T., Pitt, V., Courtney-Pratt, H., Harbrow, G., Rossiter, R. (2015). What are the primary concerns of nursing students as they prepare for and contemplate their first clinical placement experience. Nurse Educ. Pract. 15 (4), 304-309.
Lun, K. W. C. et al. (2018) 'Depression and anxiety among university students in Hong Kong', Hong Kong Medical Journal, 24(5), pp. 466-472. doi: 10.12809/hkmj176915.

Menteri Pendidikan. (2020). Surat Edaran Nomor 3 Tahun 2020 Tentang Pelaksanaan Pendidikan dalam Masa Darurat CoronaVirus (COVID-19).

Nanda. (2019). Definisi \& Klasifikasi 2018-2020. alih bahasa: Budi Anna Kelliat, et al. (Edisi 11). Jakarta: EGC

Potter dan Perry. (2010). FundamentalKeperawatan. (Edisi Kedua). Jakarta: Salemba Medika.

Quek, T. T. et al. (2019) 'The Global Prevalence of Anxiety Among Medical Students : A MetaAnalysis', Int. J. Environ. Res. Public Health, 16.

Raymond, J.M., Sheppard, K., (2017). Effects of peer mentoring on nursing students' perceived stress, sense of belonging, selfefficacy and loneliness. J. Nurs. Educ. Pract. 8 (1), 16.

Raudah, Farida, Lia Yulia Budiarti, Dhian Ririn Lestari. (2015). Stress dengan motivasi belajar mahasiswa regular fakultas kedikteran unlam yang sedang menyusun karya tulis ilmiah. DK Vol.3/No.1 hal 44-55

Sancar, B., Yalcin, A. S. and Acikgoz, I. (2018) . An examination of anxiety levels of nursing students caring for patients in terminal period. Pakistan Journal of Medical Sciences, 34(1).

Sanad, H. M. (2019) .Stress and Anxiety among Junior Nursing Students during the Initial Clinical Training : A Descriptive Study at College of Health Sciences, University of Bahrain', American Journal of Nursing Research, 7(6), pp. 995-999. doi: 10.12691/ajnr-7-6-13.

Syarifah, S. (2013).Gambaran Tingkata Mahasiswa Keperawatan Saat Menghadapi Ujin Skill Lab.Universitas Islam Negeri Syarif Hidayatullah. Skripsi. Jakarta.Diakses dari http://repository.uinjkt.ac.id/dspace/bit stream/123456789/25674/1/SITI\%2 NURUS\%20SYARIFAH\%20-\%20fkik.pdf, tgl akses 18 Nov 2018

Stuart, G.W.,(2012). Buku saku keperawatan jiwa, Edisi Revisi. Jakarta: EGC

Stuart, G.W.,(2016). Prinsip dan praktik keperawatan kesehatan jiwa stuart. Elsevier.

Sholeh, M. (2012). Terapi Shalat Tahajud Menyembuhkan Berbagai Penyakit.Jakarta: PT Mizan Publik 
Saudale, V (2016). Mahasiswa UI Diduga Gantung Diri karena Depresi. https://www.beritasatu.com/megapolita n /367736/mahasiswa-ui-gantungdirididuga-depresi. Berita Satu.com

Savitsky, Bella, Yifat Findling, Anat Ereli, Tova Hendel. (2020). Anxiety and coping strategies among nursing students during the covid-19 pandemic. Nurse Education in Practice. DOI: https://doi.org/10.1016/j.nepr.2020.1028 09

Spielberg. C. D., Gorsuch. R.L., Luschene.R., and Jacobs. G. A., (1983). State trait anxiety inventory for adults consulting psychologist. Canada: Press Inc

Taryana, A., Nur"aeni, A., dan Praptiwi, A., (2017).Tingkat kecemasan klien gagal ginjal kronik pada tindakan hemodialisis.Jurnal Keperawatan 'Aisyiyah (JKA).Vol 4 No 1.
Wawan, Jauh Hari. (2020). Diduga stres skripsi, mahasiswa yogja tewas bunuh diri dalam kos. Detiknews. https://news.detik.com/berita-jawatengah/d-4880262/diduga-stres-skripsimahasiswa-yogya-tewas-bunuh-diridalam-kos diakses 30 Mei 2020 jam 21.20

Watson, R., Rehman, S., Ali, P.A., (2017). Stressors affecting nursing students in Pakistan. Int. Nurs. Rev (Advanced Online Publication). https://doi.org/10.1111/inr.12392

World Health Organizarion. (2020). Coronavirus disease (COVID-19). https://www.who.int/docs/defaultsource/coronaviruse/situationreports/20200529-covid-19-sitrep130.pdf?sfvrsn=bf7e7f0c_4 diakses tanggal 29 Mei 2020 jam 21.00

World Health Organizarion. (2020). https://www.who.int/emergencies/disea ses/novel-coronavirus-2019/situationreports. Diakses tanggal 29 Mei jam 21.15

Zheng, Z. et al. (2020). The Mediating Effect of oping Style in the Relationship Between Depression and Disordered Eating Among Chinese Female Undergraduates. Frontiers in Psychology. Frontiers, 10, p. 3011. doi: 10.3389/fpsyg.2019.03011 